\title{
86. Ribonucleic Acid (RNA) Synthesis in Dissociated Embryonic Cells of Xenopus laevis. IV*)
}

\author{
Synthesis of Messenger RNA in the Presence of an \\ Inhibitory Factor of Ribosomal RNA Synthesis
}

\author{
By Koichiro ShIoKaWA and Kiyotaka YamanA \\ Department of Biology, Faculty of Science, Kyushu University \\ (Comm. by Yô K. OKadA, M. J. A., May 13, 1968)
}

Previous papers from our laboratory have well established that Xenopus laevis blastulae contain a factor that inhibits ribosomal RNA synthesis, but not soluble RNA, DNA, and protein syntheses. ${ }^{1), 2)}$ Its inactivity toward protein synthesis has predicted that this factor is not effective to inhibit messenger RNA synthesis.

In the present paper, messenger RNA synthesized in the isolated cells from tailbud embryos has been characterized to a certain extent and effects of the factor upon messenger RNA synthesis has been studied. The results obtained have confirmed the above prediction that the factor has no effect on the synthesis of messenger RNA.

Experimental. The methods employed in the present experiments were all those previously described.3),4) Isolated cells (referred to as T-cells) derived from tailbud embryos (stage 23-24) ${ }^{5)}$ of Xenopus laevis were labeled in the Stearns' solution ${ }^{6}$ containing either $\mathrm{H}^{3}$ uridine-5T ( $5 \mathrm{C} / \mathrm{mmole}$ ) or $\mathrm{P}^{32}$-orthophosphate (carrier-free). Cell extract ${ }^{1), 2}$ was prepared by exposing isolated cells from mid-blastulae (stage 8), and served after being partially purified by means of a charcoal column. Actinomycin D (Merck Sharp and Dohme Research Laboratories) was used at the concentration of $3 \mu \mathrm{g} / \mathrm{ml}$ which has been proved to inhibit RNA synthesis nearly completely without affecting protein synthesis at least for 4 hours. Purification and fractionation of RNA were also done as previously described. ${ }^{3), 4), 7)}$

Results and discussion. T-cells were labeled with $\mathrm{H}^{3}$-uridine for various lengths of time $(10,60$, and 240 minutes $)$ and the RNA obtained were chromatographed on methylated albuminkieselguhr (MAK) columns. There appear three major radioactivity peaks in the chromatograms (Fig. 1). The first two peaks correspond to soluble and ribosomal RNA and the last one eluted behind ribosomal RNA is here of primary concern. The results show that the increase in

*) Aided by grants from Jane Coffin Childs Memorial Fund for Medical Research and from the Ministry of Education of Japan. 

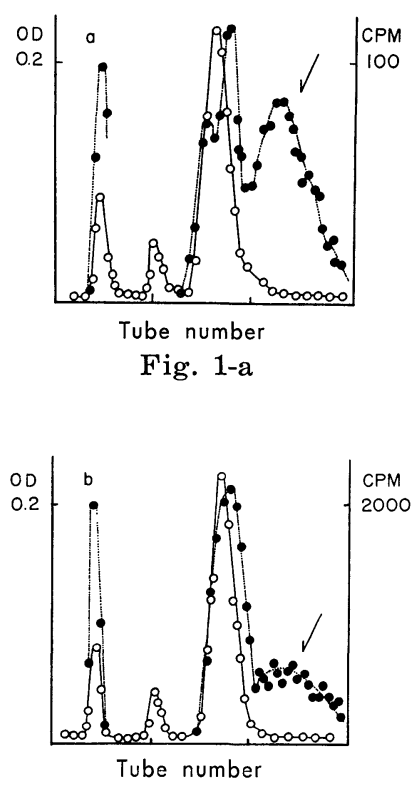

Fig. 1-b

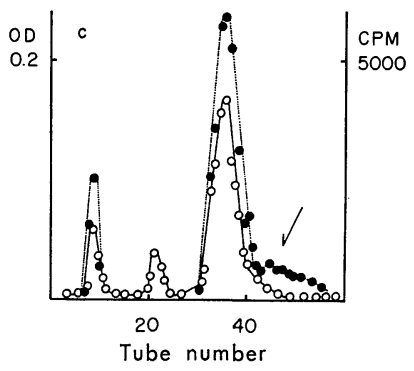

Fig. 1-c

Fig. 1. MAK column profiles of the RNA from the isolated cells labeled for varying durations. T-cells from 20 embryos were cultured in $2 \mathrm{ml}$ of the medium containing $\mathrm{H}^{3}$-uridine $(50 \mu \mathrm{C})$ for 10,60 , and 240 minutes $(a$, $b$, and $c$, respectively). The RNA was extracted at $\mathrm{pH} 5.0$ with phenolSDS-bentonite from the labeled cells, and non-radioactive tadpole RNA added as carrier. Three radioactivity peaks are, from the left, soluble, ribosomal and the RNA in question, which is indicated by an arrow. Optical density $(\bigcirc)$; radioactivity (O).
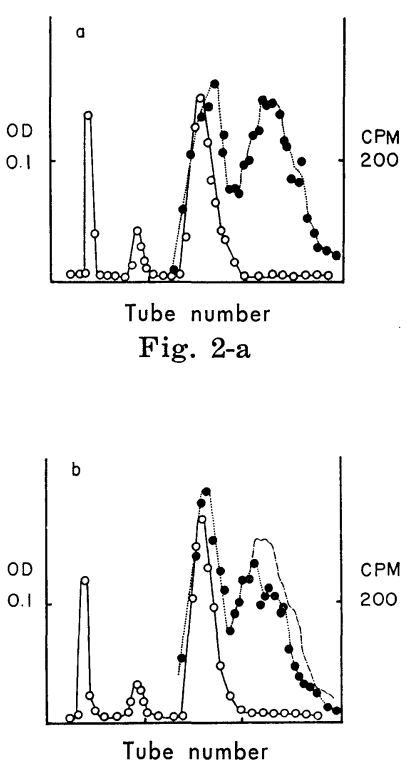

Fig. 2-b

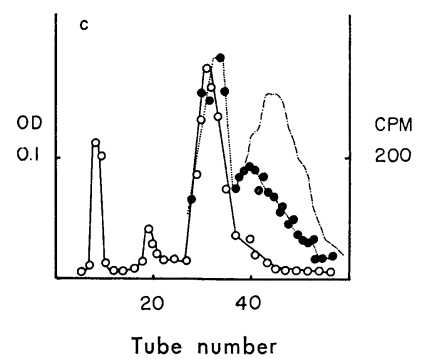

Fig. 2-c

Fig. 2. MAK column profiles showing effects of actinomycin $\mathrm{D}$ on the pulselabeled RNA. T-cells from $80 \mathrm{em}-$ bryos were cultured for 10 minutes in $8 \mathrm{ml}$ of the medium containing $\mathrm{H}^{3}$ uridine $(200 \mu \mathrm{C})$. To the cells was added actinomycin $\mathrm{D}(3 \mu \mathrm{g} / \mathrm{ml})$. The cells, equivalent to 20 embryos, were sampled after 0,10 , and 30 minutes ( $a, b$, and $c$, respectively). Extraction and fractionation of the RNA as in Fig. 1. Optical density $(O)$; radioactivity $(\mathbf{O})$. 
radioactivity of the RNA in question attained its maximum within 60 minutes and then leveled off, while the radioactivity peaks of soluble and ribosomal RNA steadily increased in height as the labeling periods became longer. Exhaustion of the label did not occur throughout the experimental period, judging from continuously increasing radioactivity incorporated into soluble and ribosomal RNA. Therefore, it can be assumed that the RNA is being synthesized rapidly and is metabolically unstable, as compared with soluble and ribosomal RNA.

After 10 minutes' labeling with $\mathrm{H}^{3}$-uridine, actinomycin $\mathrm{D}$ was added to the T-cells, which were then incubated for 0,10 , and $30 \mathrm{~min}$ utes. The results are shown in Fig. 2. About 60 per cent radioactivity of this RNA was lost during the chasing period of 30 minutes, a finding which is an additional support to the metabolical instability of the RNA. On the other hand, the remaining 40 per cent radioactivity seemed to be relatively stable, since it persisted at least 3 hours. The radioactivity incorporated into ribosomal RNA was preserved and no further accumulation was observed. This clearly demonstrates that the majority of this RNA has not been "chased" into ribosomal RNA, and the implication is that there is no precursor-product relationship between them. The same RNA as in Fig. 1a was analysed by sucrose density gradient centrifugation.?) The profile obtained (Fig. 3) is very close to that reported by Brown and Gurdon ${ }^{8)}$ for pulselabeled DNA-like RNA. This shows that the isolated cells presumably synthesize the same classes of rapidly labeled RNA as whole embryos do. The most active RNA sedimenting faster than $28 \mathrm{~S}$ RNA was then chromatographed on a MAK column. Eighty per cent of the total radioactivity applied to the column was recovered as a single peak behind ribosomal RNA (cf. Fig. 1). Therefore, the main part of the RNA which was eluted behind ribosomal RNA from a MAK column is identical with the fast sedimenting component observed in the centrifugation analysis. The $\mathrm{S}$ value of this RNA has been estimated to be approximately 35 .

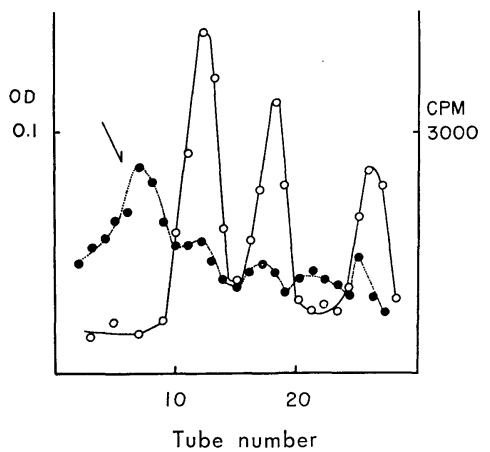

Fig. 3. Sedimentation profile of the pulse labeled RNA. T-cells were labeled and the RNA was extracted under the same condition as in the experiments shown in Fig. 1. The RNA was centrifuged for 16 hours at $25,000 \mathrm{rpm}$ through a $28-$ $\mathrm{ml} 5-20 \%$ sucrose gradient in 0.1 mM EDTA-0.01 M acetate buffer, $\mathrm{pH} 5.0$, on the RPS 25 rotor of the Hitachi 55P-2 ultracentrifuge. The radioactivity peak of the $35 \mathrm{~S} R \mathrm{RA}$ is indicated by an arrow. Optical density ( $\bigcirc)$; radioactivity (O). 
Table I. Nucleotide composition (mole \%)

\begin{tabular}{lccccc}
\hline & CMP & AMP & GMP & U(T)MP & $\begin{array}{c}\text { GC } \\
\text { content }\end{array}$ \\
\hline $\begin{array}{l}\text { RNA eluted behind } \\
\text { ribosomal RNA }\end{array}$ & 18.6 & 31.4 & 21.4 & 28.6 & 40.0 \\
Ribosomal RNA $a)$ & 24.5 & 20.4 & 34.7 & 20.4 & 59.2 \\
DNA $^{b}$ & 19.0 & 28.6 & 21.8 & 29.2 & 40.8 \\
\hline
\end{tabular}

T-cells from 20 embryos were cultured for 5 hours in $2 \mathrm{ml}$ of the medium containing $\mathrm{p}^{32}$-orthophosphate $(400 \mu \mathrm{C})$. The RNA was extracted and fractionated on a MAK column. The RNA eluted behind ribosomal RNA was precipitated with $10 \%$ TCA, collected on a Millipore filter, and then hydrolyzed with $0.5 \mathrm{~N} \mathrm{KOH}$ at $37^{\circ}$ for 18 hours, together with rat liver RNA. The resulting 2 , 3 '-nucleotides were chromatographed using a Dowex-1 $(\times 8)$ formate form column, and the radioactivity of each nucleotide was measured.

a) Shiokawa and Yamana.2)

b) Dawid. ${ }^{9)}$ The amount of 5-methylcytosine is not included.
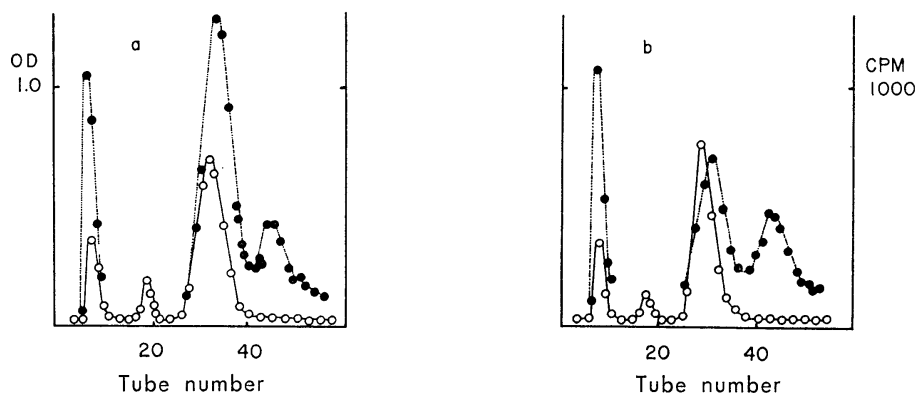

Fig. 4. MAK profiles showing effects of the cell extract on the synthesis of ribosomal RNA. T-cells from 20 embryos were cultured for 2 hours in $2 \mathrm{ml}$ of the medium containing $\mathrm{H}^{3}$-uridine $(10 \mu \mathrm{C})$ in the presence $(b)$ or absence $(a)$ of the partially purified cell extract. The extract had been prepared from 100 embryos. Optical density $(\bigcirc)$; radioactivity $(\bigcirc)$.
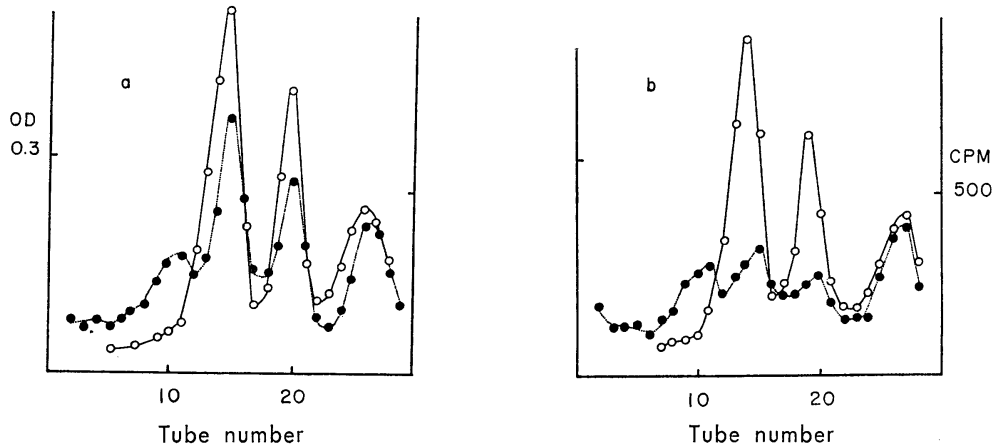

Fig. 5. Sedimentation profiles showing effects of the cell extract on the synthesis of ribosomal RNA. Portions of the same RNA as in the experiments shown in Fig. 4 was subjected to sucrose density gradient centrifugation analysis under the same condition as in Fig. 3. Optical density $(\bigcirc)$; radioactivity 
The nucleotide composition of the RNA was determined on the basis of $\mathrm{P}^{32}$-distribution among $2^{\prime}, 3^{\prime}$-monoribonucleotides, and the results compiled in Table I show that this RNA is quite different from ribosomal RNA in the nucleotide composition, but closely similar to DNA. ${ }^{9)}$

The sum of these results very strongly suggests that the RNA can be regarded as messenger RNA.

T-cells were labeled for 2 hours in the presence of a partially purified cell extract (Fig. 4). It is undoubtedly shown that, even with a remarkable depression of ribosomal RNA synthesis, there is no detectable inhibition of soluble and messenger RNA syntheses. Even after 5 hours' labeling, messenger RNA appeared as a discrete peak, owing to the reduced ribosomal RNA synthesis. This fact clearly show that messenger and ribosomal RNA syntheses are regulated independently of each other. Sucrose density gradient centrifugation analyses of the same RNA as in Fig. 4 revealed that, while 28 and $18 \mathrm{~S}$ ribosomal RNA are inhibited to the same extent, the $35 \mathrm{~S}$ RNA as well as $4 \mathrm{~S} \mathrm{RNA}$ is being synthesized normally (Fig. 5).

Previously, the syntheses of soluble RNA, DNA, and protein have been shown not to be depressed by the inhibitor. ${ }^{1), 2}$ At present, another RNA whose synthesis is resistant to the inhibitor has been demonstrated and characterized here as messenger RNA. At the same time, these results point out that the factor has high degree of specificity for ribosomal RNA synthesis.

It has already been established that messenger RNA, soluble RNA, DNA, and protein syntheses take place without a concomitant synthesis of ribosomal RNA up to late blastula stage ${ }^{10)}$ and the cytoplasm of unfertilized eggs inhibits specifically ribosomal RNA synthesis in the nuclear transplant-embryos. ${ }^{11}$ Thus, it is very likely that the inhibitor in our preparation is identical with what has been expected from Gurdon and Brown's experiments ${ }^{11)}$ and, in fact, involved in some way in the regulation of ribosomal RNA synthesis in early embryogenesis.

Acknowledgement. The authors wish to acknowledge Professor I. Kawakami for his encouragement and support to the present works.

\section{References}

1) Yamana, K., and Shiokawa, K.: Proc. Japan Acad., 42, 811-815 (1966).

2) Shiokawa, K., and Yamana, K.: Develop. Biol., 16, 389-406 (1967).

3) Yamana, K., and Shiokawa, K.: Proc. Japan Acad., 42, 806-810 (1966).

4) Shiokawa, K., and Yamana, K.: Develop. Biol., 16, 368-388 (1967). 
5) Nieuwkoop, P. D., and Faber, J.: Normal Table of Xenopus laevis (Daudin). North-Holland Publ. Co., Amsterdam (1956).

6) Stearns, R. N., and Kostellow, A. B.: In "The Chemical Basis of Development" (W. D. McElroy and B. Glass, eds.), p. 448. Johns Hopkins Press, Baltimore (1958).

7) Wada, K., Shiokawa, K., and Yamana, K.: Exptl. Cell Research (in press).

8) Brown, D. D., and Gurdon, J. B.: J. Mol. Biol., 19, 399-422 (1966).

9) Dawid, I. B.: J. Mol. Biol., 12, 581-599 (1965).

10) Brown, D. D., and Littna, E.: J. Mol. Biol., 8, 669-687 (1964).

11) Gurdon, J. B., and Brown, D. D.: J. Mol. Biol., 12, 27-35 (1965). 